\title{
Quantifying the Interaction between Root-knot Nematode (Meloidogyne incognita) and Rhizobium on Moong (Vigna radiata)
}

\author{
Neeraj $^{1 *}$ and Gurpreet Singh ${ }^{2}$ \\ ${ }^{1}$ Division of Nematology, Indian Agriculture Research Institute, New Delhi-110012, India \\ ${ }^{2}$ Department of Nematology, CCSHAU, Hisar, Haryana-125001, India \\ *Corresponding author
}

\begin{tabular}{|c|c|}
\hline & A B S T R A C T \\
\hline $\begin{array}{l}\text { Ke y w o r d s } \\
\text { Meloidogyne } \\
\text { incognita, Rhizobia, } \\
\text { Nodules, Moong \& } \\
\text { Juveniles }\end{array}$ & \multirow{3}{*}{$\begin{array}{l}\text { Interaction between Root-knot Nematode and Rhizobia was evaluated in the green house } \\
\text { on moong variety (SML-668). Seeds of the moong variety were sown in sterilized potted } \\
\text { sandy soil and inoculated with } 1000 \text { freshly hatched juveniles of root knot nematode and } \\
2 \mathrm{ml} \text { rhizobia per pot (purchased from market). Treatments were kept as } \mathrm{T}_{1} \text { (Pot without } \\
\text { nematode), } \mathrm{T}_{2} \text { (with } 1000 \mathrm{~J}_{2} \text { inoculated/pot), } \mathrm{T}_{3} \text { (with } 2 \mathrm{ml} \text { of rhizobia/pot), } \mathrm{T}_{4} \text { (pot with } \\
2 \mathrm{ml} \text { of rhizobia }+1000 \text { nematode inoculated simultaneously), } \mathrm{T}_{5} \text { (with } 1000 \mathrm{j} 2 \text { inoculated } \\
\text { one week before rhizobia) and } \mathrm{T}_{6} \text { (with } 2 \mathrm{ml} \text { of rhizobia inoculated one week before } \\
\text { nematode) and these pots were maintained for one month. Results revealed that the } \\
\text { number of nodules developing on root-knot-infected roots (nodules/seedling) was lower } \\
\text { than on healthy roots. When we added nematode simultaneously with rhizobia, singly or in } \\
\text { combination reduced the number of nodules on moongbean as compared to check plants } \\
\text { whereas nodulation is more in plants treated with rhizobia culture. }\end{array}$} \\
\hline Article Info & \\
\hline $\begin{array}{l}\text { Accepted: } \\
\text { 17 March } 2019 \\
\text { Available Online: } \\
10 \text { April } 2019\end{array}$ & \\
\hline
\end{tabular}

\section{Introduction}

Pulses are one of the major sources of protein in predominantly vegetarian diet of the people of India. They have a unique feature in plant kingdom as they are extremely endowed with the inherent ability to substantiate nitrogen enrichment of soil through root nodules from the atmospheric nitrogen. Nearly 11,000 species of legumes are known and many are important for industrial and medicinal purpose.Green gram is scientifically known as Vigna radiata and it is commonly known as mung in India. Green gram is an important pulse crop in India next to chickpea and pigeonpea and believed to be originated in
India. Green gram occupies a unique place for its use as a grain in various ways in our dietary system. Nematodes are microscopic, highly diverse biotrophic parasites. They use their stylet to feed on root as well as shoot of the plants. An estimated loss of $14.6 \%$ in developing countries and $8.8 \%$ in developed tropical and subtropical countries makes them major global challenge to ensure food security to global increasing population.

Among all Plant parasitic nematodes, Root knot nematodes are the most widely spread pests and a major threat to crops in tropical and sub-tropical regions throughout the world. Their cosmopolitan nature and 
complex strategy of parasitism makes them one of the most specialized pests. Second stage juveniles $(\mathrm{J} 2 \mathrm{~s})$ pierce root and feed on vascular cells of the plant. Mature female secrets gelatinous matrix and lays eggs partheno genetically within egg mass. Egg mass hatches upon receiving moisture and new $\mathrm{J} 2 \mathrm{~s}$ moves in soil towards the new root to parasitize. M.incognita induces below ground symptom i.e. knot or gall-like structure on host roots. This reflects as a above ground symptoms like wilting, yellowing, stunting in patches and reduced fruit sizes.

The nematodes adversely affect nodulation nitrogen fixation and yield. Meloidogyne infection, which primarily impairs water and nutrient uptake, and upward translocation by the root system. Disease complexes involving nematodes and fungal pathogens may cause significantly more crop losses than individually. Plant growth-promoting rhizobacteria (PGPR) are beneficial bacteria that colonize the rhizosphere and plant roots resulting in enhancement of plant growth or protection against certain plant pathogens. Studies were conducted to test the effect of Meloidogyne incognita and rhizobacterial inoculant to nodulation and plant growth parameters.

\section{Materials and Methods}

\section{Culture maintenance of nematode}

Seeds of Tomato cultivar Pusa Ruby were surface sterilized with $70 \%$ ethanol, solution of $0.1 \% \mathrm{SDS}+0.1 \% \mathrm{HgCl}_{2}$ and subsequently four-time washed with water. Ten pots of 15 $\mathrm{cm}$ diameter were filled with pot mixtures and used for seed sowing. Twenty days old plants were inoculated with surface sterilized 500 J2s/plant. Egg-masses were harvested 60 days post inoculation and placed over modified Baermann funnel for hatching.

\section{Preparation of pure culture of rhizobia}

The culture of rhizobia was purchased from the Department of Microbiology, CCSHAU, Hisar.

\section{Soil sterilization}

Sand brought to nematology laboratory and sterilized in autoclave at $15 \mathrm{lbs}$ pressure with $121 \pm 1^{\mathrm{O}} \mathrm{C}$ for 1 hour. Sand allowed to dry for one day and then filled in $15 \mathrm{~cm}$ diameter earthen pots (1 kg capacity).

\section{Sowing of seed}

Seeds of the Moong variety soaked in tap water for 24 hours and the sprouted seeds were sown in sterilized potted sandy soil. Seven days after sowing, one plant was retained per pot. The pots were inoculated with freshly hatched of 1000 second-stage juveniles (j2), $2 \mathrm{ml}$ of rhizobia, nematode +rhizobia and maintained for one month. Inoculation of second stage juveniles of rootknot nematode, $M$. incognita

\section{Nematode inoculation}

Inoculation of nematodes was done by carefully removing the soil around the roots of plants in each pot to ensure direct and easy approach of juveniles to root system. The nematode inoculum in the form of suspension was vigorously bubbled first and then poured on exposed roots with pipette. The roots were immediately covered with soil and light watering was done in the pots.

\section{Inoculation of rhizobia}

Rhizobia inoculation was done by carefully removing the soil around the roots of plants in each pot to root system. $2 \mathrm{ml}$ of inoculum per pot in the form of suspension was vigorously bubbled first and then poured on exposed roots with pipette. 


\section{Observation recorded}

Thirty days after inoculation each plant was uprooted carefully from soil. The roots were retrieved carefully and kept in a basin of water to clear it from adhering soil particles and recorded the following observations: plant growth characteristics (shoot length, Root length, plant weight (wt), and also on nematode multiplication such as number of galls, number of eggs/plant and number of $\mathrm{j}_{2} / 200 \mathrm{cc}$ of soil. Roots were spread in the big sized. Petri plate which contained water and recorded the observations on number of galls with the help of the hand lens. Each treatment was replicated four times. Observations on the following growth parameters and nematode reproduction factors were recorded and the data were analysed statistically

\section{Results and Discussion}

The present studies were done to explore the competition between $M$. incognita and Rhizobia on Moongbean and its effects on nodulation. The reciprocal effects of prior invasion by either nematode or bacterial inoculant on Moong were evaluated. Data in table 1 revealed that competition between $M$. incognita larvae and root-nodule bacteria was postulated as a cause of reduced nodulation on moong. Root knot Nematode forms feeding cell on the moong roots and acts as source of sink \& thus plant growth parameters affected.It is evident from the data that the plant height of mungbean declined as inoculated with the nematode. Maximum $(12.41 \mathrm{~cm})$ plant height was noted in treatment with rhizobia followed by control $(11.56 \mathrm{~cm})$ and minimum $(12.22 \mathrm{~cm})$ plant height was recorded with M.incognita, plants inoculated with nematodes were severely stunted, devitalized and looked sick.Similar trend was noticed with the root length of crop. Maximum $(14.41 \mathrm{~cm})$ root length was recorded in bacterial inoculants followed by check plant (12.83) and minimum $(9.06 \mathrm{~cm})$ in highest level. On fresh plant weight basis maximum shoot weight was recorded with rhizobial inoculant $(7.33 \mathrm{~g})$ and minimum (3.73g) with nematode. Significant and progressive decline in the plant growth parameters was noticed with inoculation of root knot nematode. Results also revealed that the number of nodules developing on root-knot-infected roots (nodules/seedling) was lower than on healthy roots. Our finding is with conformity with Taha and Raski observed that nodule formation took place either before or after the addition of larvae of $M$. javanica or Heterodera trifolii to white clover. When we added nematode simultaneously with rhizobia, singly or in combination reduced the number of nodules on moongbean as compared to check plants whereas nodulation is more in plants treated with rhizobia culture. Nutman et al., concluded that reduced nodulation occurred only as a result of overall reduction of the root system. The sites of nodule initiation are present in the cortex of the root, and more lateral roots augment the infectable potential of the root. Results also revealed that when we added nematode alonely nodulation and plant growth parameters reduced due to gall formation on the roots by $M$. incognita, by occupying space on the root system. When $M$. incognita inoculation was delayed one week prior to rhizobia there is the significant increases in nodule formation (12.6) and reduction in the number of galls and egg masses to $M$. incognita and where the nematode and bacteria was inoculated simultaneously, competition occurs, prior invasion and occupation of root surface by Root knot nematode inhibits bacteria to infect roots and there is overall hamper of process of nodulation.Similar results were found by Kumar et al 2018 thatthe root knot nematode caused significant reduction in plant height, root length fresh and dry weights of shoots and roots. 
Table.1

\begin{tabular}{|c|c|c|c|c|c|c|c|}
\hline Treatments & $\begin{array}{c}\text { Plant } \\
\text { wt.(gm) }\end{array}$ & $\begin{array}{c}\text { Shoot } \\
\text { length }(\mathrm{cm})\end{array}$ & $\begin{array}{c}\text { Root } \\
\text { length }(\mathrm{cm})\end{array}$ & $\begin{array}{c}\text { No. of } \\
\text { egg mass }\end{array}$ & $\begin{array}{l}\text { No. of } \\
\text { galls }\end{array}$ & $\begin{array}{c}\text { Final } \\
\text { nematode }\end{array}$ & $\begin{array}{c}\text { No of } \\
\text { Nodules }\end{array}$ \\
\hline Check & 6.76 & 11.56 & 12.83 & - & 0.00 & 0.00 & 0.0 \\
\hline $\begin{array}{c}\text { with } 1000 \mathrm{~J}_{2} \text { inoculated } \\
/ \text { pot }\end{array}$ & 3.73 & 7.83 & 8.83 & 19.66 & 87.5 & 266.23 & 0.0 \\
\hline $\begin{array}{l}\text { with } 2 \mathrm{ml} \text { of rhizobia } \\
\qquad / \text { pot }\end{array}$ & 7.33 & 12.41 & 14.41 & - & 0.00 & 0.00 & 18.0 \\
\hline $\begin{array}{l}\text { rhizobia + nematode } \\
\text { simultaneously }\end{array}$ & 5.33 & 9.84 & 9.93 & 9.03 & 25.3 & 89.12 & 8.5 \\
\hline $\begin{array}{l}\text { nematode inoculated } \\
\text { one week prior } \\
\text { tonematode }\end{array}$ & 4.96 & 8.13 & 8.13 & 13.3 & 45.6 & 160.15 & 6.3 \\
\hline $\begin{array}{l}\text { rhizobia inoculated one } \\
\text { week before nematode }\end{array}$ & 5.06 & 10.81 & 11.80 & 5.33 & 10.77 & 78.03 & 12.6 \\
\hline CD@ 5\% & 1.36 & 2.33 & 3.33 & 4.54 & 7.54 & 30.43 & 4.8 \\
\hline
\end{tabular}

Highest level of nematode inoculum indicated inhibitory and damaging potential on plant growth parameters on blackgram Siddiqui et al., (1993) conducted experiment on bengalgram and recorded significant decrease in rhizobial nodulation with the increase of $M$. incognita population. Jain and Trivedi (1995) also noticed that Cicer arietinumis highly susceptible to $M$. incognita leading to poor growth and nodulation and adversely affecting the quality of the produce.

They also observed that great reduction in length and weight of shoots and roots, number of nodules in plants treated with nematode prior to Rhizobium inoculation. However, significant decrease in number of galls was observed in plants treated with Rhizobium and nematode inoculation. Nayak (2006) also reported that plant height of brinjal varieties due to root-knot nematode infection were decreased by $9.04,18.48,23.50$ per cent in varieties Pusa Kranti, Kantabaigan and Pusa Purple Long, respectively over uninoculated control. Abd-Allah et al., (2010) also revealed significant reduction in nitrogen, phosphorus and potassium contents of the plant parts caused by heavy nematode infestations. These elements are needed for growth and development and ultimately for better yield.

\section{References}

Abdallah, M., Dubousset L, Meuriot F, Etienne P, Avice JC and Ourry A. 2010.Effectof mineral sulfur availability on nitrogen and sulfur uptake and remobilization during the vegetative growth of Brassica napus L., Journal of Experimental Botany, 61(10): 2635-2646.

Dilip Kumar, Jayant Bhatt and RatanLal Sharma Effect of different inoculum levels, plant age and multiplication of Meloidogyne incognita on growth of blackgram (Vigna mango L). Journal of Entomology and Zoology Studies 2018; 6(2): 452-455

Jain, C., and Trivedi PC., 1995. 'Interaction between Meloidogyne incognita andRhizobium leguminosaerum on Cicer arietinum'. Current Nematology, 6(2):155-159.

Nayak, DK. 2006. Biochemical evaluation of various metabolites as influenced by root-knot nematode, $M$. incognita in 
susceptible and resistant brinjal cultivars, Ph.D. thesis submitted to the Orissa University of Agriculture and Technology, Bhubaneswar.

Nutman, P.S., 1958. The physiology of nodule formation, p. 87-107 In: Nutrition of the legumes. E. G. Hallsworth, ed. Academic Press, New York.

Siddiqui, M.A., and Alam M.M. 1993.Evaluation of nematicidal potential in neem allelochemicals. World neem conference held at Bangalore, India, on 24th to 28th February, P.39.

Taha, A.H.Y., and D. J. RASKI. 1969. Interrelationships between root-nodule bacteria, plant-parasitic nematodes and their leguminous host. J. Nematol. 1: 201-211.

\section{How to cite this article:}

Neeraj and Gurpreet Singh. 2019. Quantifying the Interaction between Root-knot Nematode (Meloidogyne incognita) and Rhizobium on Moong (Vigna radiata). Int.J.Curr.Microbiol.App.Sci. 8(04): 2180-2184. doi: https://doi.org/10.20546/ijcmas.2019.804.256 